\title{
CHARACTERISTICS OF HUMAN RESOURCES IN SERBIAN RURAL TOURISM
}

\author{
Jelena Premović ${ }^{1}$
}

\section{Summary}

Modern consumer society affects the changes in behavior and wishes of modern tourists who require high-quality tourist service which can be provided only by highly qualified and well-trained tourism personnel. However, the education system, in almost all tourist countries doesn't follow the trends of modern tourism.

This paper analyzes demographic conditions and the basic characteristics of human resources in rural areas of Serbia. In this analysis were applied the method of induction and deduction, analysis and synthesis method, deductive and comparative methods as well as techniques of structured questionnaire. The obtained data were processed in SPSS program.

Based on the results of the original research, it was concluded that there is a positive correlation between level of education and the number of days spent on professional training of human resources and the competitive position of tourism enterprises in which human resources are working.

Key words: human resources, learning, education, rural areas, rural tourism.

JEL: L83, J11, J24, O15, Q01, Z32

\section{Introduction}

The largest part of the territory of Serbia as much as $85 \%$, according to Organization for Economic Co-operation and Development (OECD) criteria, belongs to the socalled rural areas, where live $55 \%$ of the total population in Serbia and where are most natural resources with rich ecosystems and biodiversity. Although the Serbian rural areas spread over a large part of its territory, they are in a very precarious position and are facing numerous problems (Pejanović, Njegovan, 2011). Serbia rural areas are characterized by a high degree of differentiation in terms of size and morphology of the village, natural conditions and infrastructure facilities. This differentiation is reflected also in the field of social development, demographic trends, economic development,

1 Jelena Premović, Ph.D., Municipality of Vrbas, 21460 Vrbas, Republic of Serbia, M. Tita street no. 89, Phone: +381 6414417 98, E-mail: jelena.premovic@gmail.com

EP 2016 (63) 2 (633-647) 
quality of life, environmental and other characteristics.

Limited human resources, lack of regulatory framework and funding and insufficient experience in policy formulation and operating large projects, are the major obstacles to more efficient rural development policies. As a result of this situation, there are differences in the capacity of local governments to develop and implement local rural policy (Papić, Bogdanov, 2015). As Anna Ivolga (2014) pointed out, effectiveness of rural policies directly affects living standards of people in rural areas, social and demographic situation in them, national food security, social and economic control over rural territories, and development of traditional cultures and rural way of life.

Rural tourism has been identified as a key catalyst that should activate the differentiation in the rural economy by starting new business initiatives and by finding synergies between the existing agricultural production and tourism (UNWTO, Tourism \& Leisure Advisory Services, 2011). Tourism can play a significant role in promoting rural areas as a kind of ecological oasis with a specific nature and cultural and historical heritage.

Rural tourism has a plethora of definitions, from the very minimalist one: "any tourism activity that takes place in rural areas" (Košić et al., 2015). Tourism in rural areas or rural tourism can be defined as tourism that offers the visitor a "rural environment", offering him a combination of experiences in nature, culture and people with typically rural character.

The basic assumption of the development of rural tourism consists of favorable natural and demographic conditions. Given that sustainable tourism depends mostly on the geographical physiognomy of rural areas, comparative advantages for the development of this type of tourism in Serbia are obvious.

The positive effects of sustainable development of rural tourism are numerous. Rural tourism can help lead the way to a more diversified rural economy while creating jobs and increasing income, since tourism enhances the local economy by offering opportunities for locally-processed products, handicrafts and souvenirs (Pavlović et al., 2015).

Based on the research of basic characteristics of sustainable tourism and rural areas of Serbia, as the most important benefits of sustainable rural tourism are seen to be following:

- $\quad$ protection and preservation of natural, cultural, national and historical heritage

- keeping the local population in rural area and prevention of migration to urban areas

- development of related economic and non-economic activities, primarily agriculture and services

- an increase of employment of the local population

- increase in income (and/or additional opportunities for income)

- sustainable rural development and sustainable economic development of Serbia as a whole. 
Taking into account the results of various studies that have been carried out in the country and the region, it can be assumed that for every eight new tourists to rural areas in Serbia a new direct job position is generated, additionally each 25 daily visitors present an opportunity for a new direct job position. Based on 10 years projections made on creating new jobs in Serbia arising from rural tourism that were made for the purpose of the Master Plan for sustainable development of rural tourism in Serbia, is expected to create realistic presumptions for as much as 250,000 new jobs in rural areas (Premović, 2016).

These are all reasons why rural tourism is emerging as a real possibility of development of rural areas and as an element of a better utilization of the comparative advantages of rural areas in Serbia.

\section{Data sources: Characteristics of Human Resources in Modern Tourism}

In turbulent conditions with rapid change, modern enterprises gain a competitive advantage in the market based on the so-called core competence. The core competence is the main source of competitive advantage, and it is built only through the learning process, because only foreground generated as a result of the learning process, predominantly affects the creation of added value in today's market.

In a society where the economy is based on knowledge as a backbone of comparative advantage, a key factor of the production is a group of intangible factors. They include knowledge, skills and work culture, which are gaining greater market value over time (Zubovic et al., 2015).

Human resources are the main intangible factor and source of competitiveness in modern society, but they do not create a competitive advantage a priori and per se, but it is necessary that the company its available human resources put in function of creation and achievement of competitive advantages and use them to the superior manner in comparison to the competition in the industry. In order to gain and maintain a competitive advantage realized, the company must continuously develop the knowledge, creativity, innovation of human resources, becouse successful company in the future will be the meeting place of knowledge, qualities and skills that will allow company to be always ready to react to short-term market anomalies. Each beneficial strategic plan or planning process rather than insisting on a static approach to the development of the market needs to concentrate on developing and perfecting of these capabilities that mean a willingness to seek out and seize new opportunities (Premović, 2010).

Internet and information technologies completely change the concept of education that focuses on increasing specialization and training to use different software as a tool for managing business processes. The concept of lifelong learning is no longer a matter of prestige, but a requirement for successfully performing tasks that require constant adaptation of knowledge and skills defined business objectives (Tešić et al., 2015). 
However, the human resources as well as other business resources are limited. Based on detailed research of the supply and demand of human resources has been calculated that "at the global level supply of human resources is growing at $6-7 \%$ annualy, and demand at a much higher rate of $9-11 \%$. The gap is even greater if only a segment of highly potent human resources (educated and with good practice). The strategic implication of this situation is that the survival and prosperity of enterprises depend on its ability to attract, retain and promote talent ofhuman resources"(Đuričin et al., 2009).

Radical changes in the overall socio-economic environment created under the influence of scientific and technological progress have affected also the changes in the tourism sector. The necessity that tourism constantly monitors technical and technological, cultural and other changes in order to ensure adequate and timely knowledge of the characteristics of tourist demand while adapting the tourist offer to the new needs of tourists, this confirm the role and importance of human resources in tourism. Three basic elements or factors of tourism development are: human resources, space and material basis where human resources are the first and main factor of development. Although in the literature are present thinking (especially geographers) that space is prime element in tourism development, the reality that space without the presence of human remains just a place exposed to the natural processes challenge such opinions. Meaning that designated area by human work can be made more interesting to visit and can be arranged certain tourist offer. Therefore, it must build infrastructure as one of the basic elements of the material basis. So, the man in best case the educated and professional human resources identify and evaluate natural and anthropogenic values of the area and build in it infrastructure systems, create the material basis of tourism, based on which it is organized specific tourist offer (Vujović et al., 2014).

In Programme of development of sustainable rural tourism in the Republic of Serbia (2011), development of human capital in rural tourism is pointed out as one of the priorities. Under such context, the role of professional help and support from extension service is of great assistance. Its role is getting more important, according to Čikić et al. (2015), when it takes into account that in rural tourism, attempt to create and offer authenticity is in rural hosts, mostly unprofessional, hands. They design experience based mostly on indigenous knowledge of local specifics and skills in providing services.

The basic premise on which is based this paper is that human resources especially skilled and educated human resources is the most important intangible business asset, which affects the quality of tourism services and quality of tourism activities, at whole. Starting from this premise, the main objective of paper is to show the importance of investment in continuous professional development and training of human resources who are employed in the tourism sector.

Human resources, particularly skilled and educated human resources are the most important for ensuring the quality of tourism services. Given the fact that the management of service quality is continuous process, it would and training employees to provide quality services should be active and that is acquired through working 
and learning, and once acquired skills, abilities and knowledge needed continuously upgraded and updated.

The specificity of tourism products and tourism needs undeniablly impact on the specification of human resources that actively participate in the creation of tourism and providing tourist services.

The seasonal nature of tourist activities causes and „seasonal“ needs for human resources in tourism. The needs for human resources in the entire tourism sector during the period of the season are high, which affects the attractiveness of tourism employment in the so-called peak tourist season in certain destinations and periods that are in summer and during weekends, holidays and at night. Working hours are extended in these situations and earnings are growing. However, in the off-season, the situation is diametrically opposite. Uncertainty in the execution of conditional "job security-employment" creates major problems for managers of tourism enterprises in the recruitment, selection and engagement of adequate special tourism staff for a longer period. The mobility of human resources in tourism is much more pronounced than in other service industries. Incomes or income which is realized in the tourism industry are usually low, except during the peak tourist season. Also, when analyzing the human resources involved in the performance of the tourist accommodation activities, it can be noted that their qualification basis is very low.

On the other hand, the modern consumer society affects the behavior changes and the desire of modern tourists who require high-quality and sophisticated services that can provide only highly qualified and well-trained tourism personnel.

Because of growing perceptions and preferences of future tourists in terms of demand for high-quality tourist products, and especially tourist services, human resources, which are employed in the tourism sector, and actively participate in the creation of tourism and providing tourist services, must constantly improve their knowledge and skills. Not only because of increasing competition in the tourism market, but also to discover new tourist destinations and content in them, which will satisfy the wishes and needs of modern tourists for new experiences and adventures.

\section{Metodology: Characteristics of demographic structure of rural population in Serbia}

Although rural areas are more and more alike urban areas in social and infrastructural terms, farm users are still different from urban residents as regards their behaviour, sense of community spirit, greater piousness (Chmieliński, Chmielewska, 2015). Rural area of Serbia is naturally compact and anthropogenically highly heterogeneous environment. This gives it a great challenging opportunity for multipurpose utilization of the various subtypes of rural tourism (Milenković, Utvić, 2013).

This paper analyzes demographic conditions and the basic characteristics of human resources in rural areas of Serbia. In this analysis were applied: the method of induction 
and deduction, the method of analysis and synthesis method, deductive and comparative methods, as well as techniques of structured questionnaire for field research. The obtained data were processed in SPSS program.

The territory of the Republic of Serbia covers an area of $88,509 \mathrm{~km}^{2}$ of wich is settled 6,158 populated places of which 193 are cities or 3.1\% in urban areas and 5,965 are other settlements which are automatically considered rural (without Kosovo and Metohia). The average population density in Serbia is 92.6 citizens per $1 \mathrm{~km}^{2}$, while it is much lower in villages or rural areas.

Demographic trends are more and more unfavorable, which is especially noticeable in rural areas of the country. Namely, according to the census of year 2011 from Statistical Office of the Republic of Serbia, in the period from 2002 to 2011, the total population has decreased by $4.15 \%$, while in rural areas decreased by as much as $10.9 \%$ or 311 139 residents, so that today the rural population makes $40.6 \%$ of the total population of Serbia.

One of the key characteristics of the demographic structure of the rural population in Serbia is unfavorable age structure (Table 1). Coefficient of age dependency in Serbia is 30.4 while in the region of Southern and Eastern Serbia its biggest value is as high as 38.3. This means that for every resident over the age of 65 years comes almost four of those aged 15-64. The values of the coefficient of age dependency were only slightly more favorable in the region of Belgrade where it is 22.9 and Vojvodina, which has a value of 25.2 .

Table 1. Age structure of the rural population in Serbia

\begin{tabular}{|c|c|c|c|c|c|}
\hline \multirow{2}{*}{$\begin{array}{l}\text { REGIONS } \\
\text { IN } \\
\text { SERBIA } \\
\end{array}$} & \multicolumn{3}{|c|}{$\begin{array}{c}\text { Age structure } \\
(\%)\end{array}$} & \multirow{2}{*}{$\begin{array}{c}\text { Coefficient of age } \\
\text { dependency }\end{array}$} & \multirow{2}{*}{$\begin{array}{c}\text { Ratio of } \\
\text { young and old } \\
\text { people }\end{array}$} \\
\hline & $0-14$ & 14-64 & $65+$ & & \\
\hline SERBIA & 13.9 & 66.0 & 20.1 & 30.4 & 69.3 \\
\hline BELGRADE REGION & 15.0 & 69.1 & 15.8 & 22.9 & 95.2 \\
\hline VOJVODINA REGION & 14.3 & 68.5 & 17.3 & 25.2 & 82.7 \\
\hline $\begin{array}{l}\text { ŠUMADIJA AND WESTERN } \\
\text { SERBIA REGION }\end{array}$ & 14.1 & 65.3 & 20.6 & 31.5 & 68.7 \\
\hline $\begin{array}{l}\text { SOUTHERN AND EASTERN } \\
\text { SERBIA REGION }\end{array}$ & 12.8 & 63.1 & 24.1 & 38.3 & 52.9 \\
\hline
\end{tabular}

Source: Ministry of Agriculture, Forestry and Water Management of the Republic of Serbia, 2013;

An important indicator in the analysis of the age structure represents the ratio of young and old people. The average value of this indicator in Serbia was 69.3. The limit value of the relationship of young and old population, Belgrade has the highest value of 95.2, while in the region of Southern and Eastern Serbia the most unfavorable value of this indicator, because for every 100 people older than 65 years, there has only 53 residents under the age of 15 years. 
When analyzing the educational structure of the rural population of Serbia older than 15 years, the situation is as follows: for the first time there are more persons with secondary education $(37 \%)$ compared to illiterate persons or persons who have completed primary school education (15\%). In addition to this positive trend is noticed and reducing the number of highly educated population in all rural regions of the country, except in the province of Vojvodina.

Revenues generated by the rural population of Serbia in the highest percentage of 35 to $42 \%$ derived from employment income, followed by the share of pensions with a growing tendency since 2006 , the share of pensions amounted to about $20 \%$, to be increased in 2012 by as much as $10 \%$, so that today pensions make up almost a third of the revenue structure of the rural population. Natural consumption is the third largest share in the revenue structure of the rural population of Serbia, while revenues from agriculture with a share of $7.6 \%$ take fourth place in this structure. Specific data on the structure of income of the rural population in Serbia, which were realized in the period from year 2006 to year 2012, are shown in the following table.

Table 2. Structure of income of the rural population in Serbia

\begin{tabular}{|l|l|l|l|l|l|l|l|}
\hline $\begin{array}{l}\text { STRUCTURE OF INCOMES- } \\
\text { REVENUES }\end{array}$ & $\mathbf{2 0 0 6}$ & $\mathbf{2 0 0 7}$ & $\mathbf{2 0 0 8}$ & $\mathbf{2 0 0 9}$ & $\mathbf{2 0 1 0}$ & $\mathbf{2 0 1 1}$ & $\mathbf{2 0 1 2}$ \\
\hline Employment income & 38.9 & 37.1 & 42.1 & 39.9 & 36.3 & 36.9 & 35.7 \\
\hline Pensions & 19.7 & 23.1 & 24.2 & 26.6 & 29.5 & 36.8 & 30.2 \\
\hline Revenues from agriculture & 7.8 & 6.8 & 8.3 & 6.8 & 9.3 & 7.8 & 7.6 \\
\hline Natural consumption & 14.8 & 14.7 & 12.7 & 12.6 & 12.4 & 13.9 & 13.2 \\
\hline Others: & 18.8 & 18.3 & 12.7 & 14.1 & 12.5 & 14.6 & 13.3 \\
\hline
\end{tabular}

Source: Ministry of Agriculture, Forestry and Water Management of the Republic of Serbia, 2013;

In rural areas of Serbia is very strong gender inequality in terms of economic independence. Among the female population is less active participation of people, fewer employees and fewer women working outside agriculture than in men population. Broken down by regions, in all segments of the labor market disadvantage of women is particularly acute in Southern and Eastern Serbia, while slightly more favorable in Vojvodina. Besides expressed gender dissproportions, the participation of young people in rural areas is also very unfavorable. In support of expressed oppinion the data says that every fifth resident of rural areas aged from 15 to 24 is employed in the service industry, but the participation of young people from 15 to 34 years old in the overall rate of unemployment is $15.5 \%$.

Based on the analysis of demographic structure of the rural population of Serbia, which is viewed from the aspect of age, education and gender structure, and the structure of revenues earned, it can be concluded that although rural areas of Serbia have the natural resources and rich cultural and historical heritage, tendencies of depopulation of these 
areas are evident, and economic implications of this discharge are apparent.

In order to stop the further uncontrolled exploitation and degradation of natural resources and to improve the situation in rural areas of Serbia it has formed a support network for rural development consisting of nine regional centers. The final objective of these regional centers, which are organized in the form of special office is the promotion of agriculture, is the creation of better living and working conditions and reducing poverty in rural areas. Network for support rural development supports the development of rural areas or villages and their residents through the project goals and sub-objectives.

It is expected that an effective system of transfer of knowledge, technology and information, as well as an innovative way of using the potential of cultural and historical heritage and biodiversity will impact on increasing the attractiveness of rural areas and the realization of the outlined strategic goals for rural development.

\section{Results with discussion: Empirical research of human resources in tourism sector in Serbia}

Systematic and continuous implementation of the process of learning and education becomes one of the most important forms of development of tourism personnel. However, the education system in almost all tourist countries does not follow the trends of modern tourism.

Researches from professors Vidoje Stefanović and Dobrica Jovičić (2010) has shown that the most frequently mentioned weaknesses in the tourism sector are: the lack of basic knowledge and skills of tourism products and services, target market areas, marketing, sales, focus on consumers and electronic data processing of reservations via the Internet. Also, employees are missing and inter-peronnel skills, especially in matters of development of human resources and direct contact with consumers.

By analyzing the structure and educational level of employees in tourism in local markets, a professor Svetislav Milenković noted that the qualification of employees in the accommodation sector is at grassroots level as well as their structure, as evidenced the data are presented in the Table 3.

Table 3. Qualification and structure of employees in tourism sector in Serbia

\begin{tabular}{|l|c|c|c|}
\hline \multicolumn{1}{|c|}{$\begin{array}{c}\text { DEGREE } \\
\text { OF } \\
\text { EDUCATION }\end{array}$} & $\begin{array}{c}\text { PARTICIPATION IN } \\
\text { TOURISM } \\
\text { (basic and additional) }\end{array}$ & $\begin{array}{c}\text { STRUCTURE OF } \\
\text { EMPLOYEES }\end{array}$ & $\begin{array}{c}\text { PARTICIPATION IN } \\
\text { TOURISM }\end{array}$ \\
\hline $\begin{array}{l}\text { HIGH HIGHER } \\
\text { EDUCATION } \\
\text { (classic VII-1 and VI level } \\
\text { of education and master or } \\
\text { bachelor according to Bologna } \\
\text { standard) }\end{array}$ & $4 \%$ & MANAGERS & $6 \%$ \\
\hline
\end{tabular}




\begin{tabular}{|l|c|c|c|}
\hline $\begin{array}{l}\text { HIGHSCHOOL } \\
\text { EDUCATION }\end{array}$ & $9 \%$ & $\begin{array}{l}\text { SUPERVISORY } \\
\text { AUTHORITIES }\end{array}$ & $8 \%$ \\
\hline $\begin{array}{l}\text { ELEMENTARY } \\
\text { EDUCATION } \\
\text { (classic 8 year education) }\end{array}$ & $75 \%$ & $\begin{array}{c}\text { TECHICAL } \\
\text { SUPPORT }\end{array}$ & $22 \%$ \\
\hline $\begin{array}{l}\text { W T T O U T H } \\
\text { E E M E N T A R Y } \\
\text { EDUCATION }\end{array}$ & $38 \%$ & OPERATIONS & $64 \%$ \\
\hline
\end{tabular}

Source: Milenković, 2009;

What is the importance of type, in other words the level of education, on the quality and efficiency of every employee, shows also the latest research in which it is calculated that "primary education increases the working capacity of $30-40 \%$, medium for $100 \%$ and higher education and up to $300 \%$. Therefore, it "must be emphasized that education has an economic function, because the educators are one of the essential factors for the development of the productive forces and the increase in labor productivity in society, and thus also for improvement of human development" (Kovačević, 2012).

Starting from the prior knowing and with aim to determine the real situation in the tourism sector in Serbia, it was conducted concrete empirical research by interviewing employees by applying the techniques of structured questionnaires.

On the territory of the Republic of Serbia which is $88,509 \mathrm{~km}^{2}$ live $7,186,862$ inhabitants. The employment rate in the tourism sector in 2013 amounted to $1.71 \%$, while the average net salary was 24.362 dinars which is almost twice less than the average net salary in the Republic of Serbia at 43.932 dinars in the same period.

To put its comparative tourism potential to operate at achieving higher employment rates and competitive advantages Serbia must, above all, invest in continuous professional development and training of personnel who are employed in the tourism sector. Increasing the rate of employment in the tourism sector and the continuous improvement of the quality of human resources involved in the creation of tourism and providing tourist services will positively affect the development of tourism, which should become one of the most important drivers of overall economic development of the country in the coming period.

In order to prove the claims or the basic hypotheses of research which states: Continuous and designed human resources management is needed in order to create the necessary (pre) conditions for gaining competitive advantages and successful operation of tourism enterprises, it was conducted and concrete empirical research.

The original empirical research was conducted through a survey - Questionnaire for the analysis of human resources in the tourism sector of Serbia and was conducted on the territory of Serbia in 2013. The questionnaire was circulated in two ways: "Face to Face" - personal contact and communication during the survey of employees in the tourism sector, as well as electronically - sending e-mails. The purpose of the 
survey is to collect concrete data by respondents who are employed in companies, tourist organizations, agencies, institutions and other legal and natural persons who directly and/or indirectly are involved in the creation of tourist offer and in providing tourist services on the territory of Serbia. For data processing was used SPSS program that runs under Microsoft Windows environment. From quantitative methods were applied descriptive statistics, $t$ test for independent samples, correlation and analysis of variance. For the purposes of processing data it was used registration of frequencies and calculation of the percentage as well as the arithmetic mean for determination of the mean values (Premović, 2015).

Based on the answers of 141 examinees - human resources who are engaged in tourist activities in Serbia, the data on prevalent age and educational structure of tourist companies and their employees are obtained and after statistical processing shown in the table below.

Table 4. Age and educational structure in the tourism sector in Serbia

\begin{tabular}{|c|c|l|c|}
\hline \multicolumn{2}{|c|}{$\begin{array}{c}\text { Age structure in the tourism sector Serbia } \\
(\%)\end{array}$} & \multicolumn{2}{c|}{$\begin{array}{c}\text { Educational structure in the tourism sector } \\
\text { Serbia } \\
(\%)\end{array}$} \\
\hline Age: & $\begin{array}{c}\text { Enterprices } \\
\text { (prevailing structure) }\end{array}$ & The level of education & $\begin{array}{c}\text { Enterprices } \\
\text { (prevailing structure) }\end{array}$ \\
\hline$<25$ & $/$ & $\begin{array}{l}\text { Doctorate / } \\
\text { Master }\end{array}$ & $/$ \\
\hline $26-32$ & $4.3 \%$ & High education & $38.2 \%$ \\
\hline $33-40$ & $41.1 \%$ & Bachelor & $13.7 \%$ \\
\hline $41-55$ & $51.8 \%$ & High school education & $48.1 \%$ \\
\hline$>56$ & $0.7 \%$ & $\begin{array}{l}\text { Lower medium and / or } \\
\text { primary and lower }\end{array}$ & $/$ \\
\hline
\end{tabular}

Source: Authors' calculation based on the survey data

It can be noticed that the middle-aged employees prevail in the tourist companies. In the half of the companies, the employees aged from 41-55 are dominant, and the smallest number of employees in tourist companies in Serbia is older than 56. In 40\% of the companies the highest number of employees is aged between 33 and 40, whereas there are no companies in which employees younger than 25 prevail. Tourist staff who graduated from secondary schools prevails in tourist companies in Serbia in which the examinees are employed. According to the survey, 50.04\% of examinees have a university degree or academic studies of the 2 nd degree -master. $36.9 \%$ of employees have a secondary school diploma, while every tenth employee has a bachelor degree.

The research results show that the educational structure of the employees in tourist companies encompassed by the survey is notably different from the starting researches since the university degree is the dominant level of education with more than $60 \%$.

Ownership-management structure of the companies which employ the examinees has also been analyzed. The results of this specific research are shown in the following table. 
Table 5. Ownership-management structure of the companies in the tourism sector in Serbia

\begin{tabular}{|l|c|l|c|}
\hline \multicolumn{2}{|c|}{$\begin{array}{c}\text { OWNERSIP STRUCTURE OF THE } \\
\text { COMPANIES }\end{array}$} & \multicolumn{2}{c|}{$\begin{array}{c}\text { MANAGEMENT STRUCTURE OF THE } \\
\text { COMPANIES }\end{array}$} \\
\hline Form of ownership: & $\begin{array}{c}\text { Companies } \\
\text { (prevailing structure) }\end{array}$ & Form of management: & $\begin{array}{c}\text { Companies } \\
\text { prevailing structure) }\end{array}$ \\
\hline $\begin{array}{l}\text { State-owned (Republic, } \\
\text { Province, } \\
\text { a u th o rit i e s-c i ty - } \\
\text { municipality) }\end{array}$ & $33.3 \%$ & Managers & $23.5 \%$ \\
\hline Private & $48.9 \%$ & $\begin{array}{l}\text { Professional-technical } \\
\text { staff }\end{array}$ & $31.3 \%$ \\
\hline Mixed & $5 \%$ & Administrative staff & $37.5 \%$ \\
\hline Stake-holders & $22.3 \%$ & $\begin{array}{l}\text { Physical and supporting } \\
\text { staff }\end{array}$ & $6.5 \%$ \\
\hline Other & $0.7 \%$ & Other & $1.2 \%$ \\
\hline
\end{tabular}

Source: Authors' calculation based on the survey data

After analyzing ownership-management structure of companies, the obtained empirical data lead to the following conclusions:

- The surveyed examinees are mostly employed in the private-owned companies (69). There are 47 state-owned companies. They are followed by stake-held companies (16) and mixed companies (7).

- The administrative staff is dominant with $37.5 \%$ in the management structure of the companies; slightly smaller percentage of participation of $31.3 \%$ has professional-technical staff. The representation of managers is $23,5 \%$ on the average, while based on the results of empirical research, the physical and supporting staff is the least present.

In performing tourist activity and providing tourist services, continuous training and education of human resources have a particularly important role, which is why ,tourist companies have to allocate additional resources for intensive training of personnel (rule of successful companies becomes that each employee needs to spend some time in the „classroom“). What are the services provided by tourism enterprises more sophisticated, with more built-in knowledge, it is also mandatory time spent in education longer. For managers, it is estimated that they need to spend over a fifth of their working time in their own education, in order to prevent ,the obsolescence of knowledge. “This means that the knowledge service time shorter, so that it can no longer live by the „old glory“" ie. Knowledge gained in an earlier era. (Milenković, 2009).

Accepting cited above paragraphs, and in order to obtain specific data on the amount of additional funds allocated for the improvement of knowledge and education of human resources in tourist enterprises on the territory of Serbia, was conducted original research. Obtained results show that the largest number of companies to allocate $1 \%$, 
while the least of those tourism enterprises that annually allocate over $10 \%$ of the revenues for the improvement of knowledge and education employees.

When is included in the analysis also data on the participation of employees in various forms of professional training and the number of days spent on professional training, there are received following results: around $60 \%$ of employees conducted by an average of up to 5 days at various training programs and education, while one in four employees spent more than 10 days. Companies in which $25 \%$ of employees spent 10 days or more on vocational training have a better or superior position in the tourism market of Serbia and these companies allocate more additional funds for various forms of professional training and education of employees. In $40 \%$ of the company's half or more employees passed various types of vocational training and education, while in $20 \%$ of enterprises training was provided to every fifth employee.

\section{Conclusion}

Research that is on Serbian territory enforced by the ministry responsible for tourism have shown that the key of success of rural tourism development should be sought in the optimal utilization of the potential of rural areas, active effort, modern approach, quality staff and managers, and in good use of known instruments of stimulating local economic development.

Based on the results of the original research conducted within the tourism entities on the territory of Serbia, it was concluded that there is a positive correlation between level of education and the number of days spent on professional training of human resources on the one side and the competitive position of tourism enterprises in which human resources are working on the other side.

If tourism wants to achive its role as one of key generators of economic development in Serbia, it is essential that human resources working in the tourism sector have the knowledge, skills and abilities, as well as to continuously manages their professional training and development.

However, particulary low educational structure of human resources involved in the provision of services in rural tourism can be considered as one of the most important factors that hinder the economic development of rural areas as it is in it reason for the low entrepreneurial potential of rural residents, as well as causing high economic interest of foreign investors. In support of this satetment speaks official statistics according to which $97 \%$ of the rural population has not attended additional training programs, and $54 \%$ have no specific knowledge and skills, as well as the fact that in Serbia there are still no specific organized training programs and educaiton of the rural population in the provision of services in rural tourism, which is necessary to change in the future. 


\section{Literature}

1. Chmieliński, P., Chmielewska, B. (2015): Social changes in rural areas: incomes and expenditures of rural households, Economics of Agriculture, vol. 62, no. 4, pp. 907-920, The Balkan Scientific Association of Agrarian Economists, Belgrade, Institute of Agricultural Economics, Belgrade, Academy of Economic Studies, Bucharest, Belgrade, Serbia.

2. Čikić, J., Petrović, M., Đurđev, B. (2015): Diffusion of knowledge and rural tourism development - example of Vojvodina, Economics of Agriculture, vol. 62, no. 1, pp. 123-136, The Balkan Scientific Association of Agrarian Economists, Belgrade, Institute of Agricultural Economics, Belgrade, Academy of Economic Studies, Bucharest, Belgrade, Serbia.

3. Đuričin, D., Janošević, S., Kaličanin, Đ. (2009): Menadžment i strategija, Centar za izdavačku delatnost, Univerzitet u Beogradu, Ekonomski fakultet, Beograd, Srbija.

4. Ivolga, A. (2014): Overview of contemporary issues of sustainable rural development in Russia in terms of existing differences between regions, Economics of Agriculture, vol. 61, no. 2, pp. 331-345, The Balkan Scientific Association of Agrarian Economists, Belgrade, Institute of Agricultural Economics, Belgrade, Academy of Economic Studies, Bucharest, Belgrade, Serbia.

5. Košić, K., Demirović, D., Pejanović, R., Lazić, L., Stamenković, I. (2015): Key principles of rural tourism households development strategy-case study of Vojvodina, Economics of Agriculture, vol. 62, no. 4, pp. 975-988, The Balkan Scientific Association of Agrarian Economists, Belgrade, Institute of Agricultural Economics, Belgrade, Academy of Economic Studies, Bucharest, Belgrade, Serbia.

6. Kovačević, B. (2012): Uticaj nivoa obrazovanja na zadovoljstvo humanog kapitala u turističko-hotelijerskom poslovanju, Škola biznisa 2/2012, pp. 4959, Beograd, Srbija.

7. Milenković, S. (2009): Turizam i ekonomija, monografija, Univerzitet u Kragujevcu, Ekonomski fakultet Kragujevac, Kragujevac, Srbija.

8. Milenković, S., Utvić, S. (2013): The challenges of rural areas in Serbia promising tourist activities, Economics of Agriculture, vol. 60, no. 1, The Balkan Scientific Association of Agrarian Economists, Belgrade, Institute of Agricultural Economics, Belgrade, Academy of Economic Studies, Bucharest, Belgrade, Serbia.

9. Ministarstvo poljoprivrede, šumarstva i vodoprivrede Republike Srbije. (2013): Nacrt Strategije poljoprivrede i ruralnog razvoja Republike Srbije (2014-2024), Beograd, Srbija.

10. Papić, R., Bogdanov, N. (2015): Rural development policy - a perspective of 
local actors in Serbia, Economics of Agriculture, vol. LXII, no. 4, pp. 10791093, The Balkan Scientific Association of Agrarian Economists, Belgrade, Institute of Agricultural Economics, Belgrade, Academy of Economic Studies, Bucharest, Belgrade, Serbia.

11. Pavlović, N., Medić, S., Tešić, A. (2015): Relations, interactions and networks of cultural tourism stakeholders in rural areas of Vojvodina, Economics of Agriculture, vol. 62, no. 2, pp. 481-495, The Balkan Scientific Association of Agrarian Economists, Belgrade, Institute of Agricultural Economics, Belgrade, Academy of Economic Studies, Bucharest, Belgrade, Serbia.

12. Pejanović, R., Njegovan, Z. (2011): Ruralni razvoj i lokalni ekonomski razvoj AP Vojvodine, monografija, Univerzitet u Novom Sadu, Poljoprivredni fakultet, Novi Sad, Srbija.

13. Premović, J. (2010): Inovativne organizacije u funkciji ostvarivanja konkurentske prednosti, Montenegrin Journal of Economics, vol. 6, no. 11, pp. 157-163, Kotor, Crna Gora.

14. Premović, J. (2015): Ljudski resursi kao strateški potencijal održivog turističkog razvoja Srbije, doktorska disertacija, Ekonomski fakultet Kragujevac, Univerzitet u Kragujevcu, Kragujevac, Srbija.

15. Premović, J. (2016): Obrazovna struktura kadrova: neophodna ulaganja u edukaciju turističkih kadrova, Poljoprivrednikov poljoprivredni kalendar 2016: nova znanja, dostignuća, iskustva, pp. 50-51, „Dnevnik-Poljoprivrednik“ AD Novi Sad, Novi Sad, Srbija.

16. Republički zavod za statistiku. (2012): Popis stanovništva, domaćinstava $i$ stanova u Republici Srbiji, Beograd, Srbija, (available at: www.popis2011.stat. rs).

17. Stefanović, V., Jovičić, D. (2010): Neophodnost „znanja o znanju “ u turizmu, Glasnik srpskog geografskog društva, broj 3/2010, pp. 53-62, Srpsko geografsko društvo, Beograd, Srbija.

18. Tesić, A., Iić, V., Đelić, A. T. (2015): Labour market in Serbia - an opportunity or limitation of economic growth, Economics of Agriculture, vol. 62, no. 4, pp. 1117-1136, The Balkan Scientific Association of Agrarian Economists, Belgrade, Institute of Agricultural Economics, Belgrade, Academy of Economic Studies, Bucharest, Belgrade, Serbia.

19. Vujović, S., Premović, J., Grujić, B. (2014): Kadrovi u turizmu, Ekonomski vidici, godina 19, br. 4/2014, str. 437-447, Društvo ekonomista Beograda, Beograd, Srbija.

20. UNWTO, Tourism \& Leisure Advisory Services. (2011): Master plan održivog razvoja ruralnog turizma u Srbiji, jun 2011, Beograd, Srbija.

21. Zubović, J., Jeločnik, M., Subić, J. (2015): Can human resources induce sustainability in business? Modeling, testing and correlating $h r$ index and 
company's business results, Economics of Agriculture, vol. 62, no. 2, pp. 399420, The Balkan Scientific Association of Agrarian Economists, Belgrade, Institute of Agricultural Economics, Belgrade, Academy of Economic Studies, Bucharest, Belgrade, Serbia.

\section{SPECIFIČNOSTI LJUDSKIH RESURSA U RURALNOM TURIZMU SRBIJE}

\section{Jelena Premović ${ }^{2}$}

\section{Rezime}

Savremeno potrošačko društvo utiče na promene u ponašanju i željama savremenih turista koji zahtevaju visokokvalitetnu turističku uslugu koju može pružiti jedino visoko kvalifikovan i kvalitetno obučen turistički kadar. Međutim, obrazovni sistem u skoro svim turističkim zemljama ne prati trendove modernog turizma.

U radu su analizirani demografski uslovi i osnovne karakteristike ljudskih resursa $u$ ruralnim područjima Srbije. U ovoj analizi su primenjene metode indukcije i dedukcije, analize $i$ sinteze, deduktivna i komparativna metoda kao i tehnika strukturiranog upitnika za terensko istraživanje. Dobijeni podaci su obrađeni u programu SPSS.

Na osnovu rezultata originalnog istraživanja, došlo se do zaključka da postoji pozitivna korelacija između stepena obrazovanja i broja dana provedenih na stručnom usavršavanju ljudskih resursa i konkurentske pozicije turističkih preduzeća u kojima ljudski resursi rade.

Ključne reči: ljudski resursi, učenje, obrazovanje, ruralna područja, ruralni turizam.

2 Dr Jelena Premović, Opštinska uprava Vrbas, 21460 Vrbas, Srbija, M. Tita 89, Telefon: +381(0) 6414417 98, E-mail: jelena.premovic@gmail.com

EP 2016 (63) 2 (633-647) 